\title{
El Señor del Mezquital: Un Cristo de caña del siglo xvı en D urango
}

A MEDIDA QUe CAminamos hacia el norte de M éxico, los vestigios culturales de los siglos xvi y xvir se van haciendo más escasos debido a que hubo una concentración humana menos numerosa que en el sur, lo cual propició que un menor número de obras artísticas llegaran a estos lugares. Además, las generaciones que se van sucediendo se olvidan con facilidad del significado que los objetos tuvieron para las anteriores y los reemplazan por nuevos, así que la mayoría de objetos de esos siglos se ha perdido.

Éste es el caso de los Cristos de caña de maíz que fueron llevados por los religiosos en los primeros tiempos de la Colonia. $\mathrm{H}$ asta ahora solamente se sabe de la existencia de dos de estas imágenes en el territorio del actual estado de Durango: la del Señor del M ezquital y la del Señor de la Caridad que perteneció al hospital de $\mathrm{N}$ ombre de Dios, el cual se encuentra en el templo de Jesús $\mathrm{N}$ azareno de ese lugar.

La historia del Señor del M ezquital fue escrita por primera vez en ${ }^{7} 737$ por el cronista franciscano José Arlegui, quien fue guardián del convento de San Antonio de Durango. Este religioso recogió la tradición oral que sobre este C risto había en la ciudad, y buscó sustentarla con algún documento. Recurrió a Juan de Aragón, notario del Santo O ficio y secretario de varios obispos, quien al referirle la historia le aseguró que en el archivo de la mitra de Durango había una información (actualmente desaparecida) sobre el 
Cristo del M ezquital. Arlegui vertió la información de Aragón en su crónica sobre la provincia franciscana de Zacatecas, ${ }^{1}$ con el afán de hacer ver las dificultades que tuvieron los franciscanos en la conversión de los indígenas. Gracias a este libro conocemos la historia de la imagen.

D e acuerdo con Arlegui, durante la rebelión de la nación tepehuana contra los españoles en I6I6, los indígenas destruyeron el convento y la iglesia de San Francisco del M ezquital. Este convento había sido fundado por los franciscanos, probablemente en $1588,{ }^{2}$ a 8 o kilómetros al sur de la ciudad de Durango, con el fin de cristianizar a los tepehuanes que habitan en las abruptas serranías del sur del estado de Durango. Arlegui refiere que en la iglesia del M ezquital estaban unas imágenes de C risto y de la Virgen a las cuales los tepehuanes agredieron. A la Virgen le dieron "un hachazo en el rostro, cuya cicatriz aún persevera hoy día". Éste es el primer error en que incurrió el cronista, que escribió sobre estos hechos cien años después de que habían acontecido, ya que confundió la Virgen del Mezquital con la del Zape, que de acuerdo con la tradición fue la que sufrió una herida de ese tipo. Del Cristo dice: "La imagen de Jesús crucificado estaba y aún permanece, con un flechazo en la espinilla, de que salió una gota de sangre, que aún hoy la registra la vista."

Ambas imágenes fueron trasladadas a Durango cuando los españoles recuperaron la plaza del M ezquital, y Arlegui para reforzar la pertenencia del Cristo a la orden franciscana refiere una tradición que fue muy común entre las imágenes famosas de la Colonia: un sacerdote trató de colocar al Cristo en la catedral pero "por más que se esforzó a levantarle del suelo, no pudo ni moverle del sitio en que se hallaba". Un franciscano, con el fin de llevarlo al templo de San Francisco, lo pudo levantar en el aire como si fuera de paja, dice el piadoso cronista. Las imágenes permanecieron en San Francisco hasta I9I7 cuando tanto el templo como el convento fueron derribados. ${ }^{3}$ Fueron trasladadas entonces a la catedral, en donde la imagen de la Virgen fue colocada en una de las capillas laterales y el Cristo en la sacristía menor. Con el paso del tiempo fue olvidado.

I. José Arlegui, Chronica de la provindia de N. S. P. S. Frandso de Zacatecas $(I 737)$, con apéndice de Antonio Gálvez en I827, M éxico, Cumplido, 1851, pp. 56-57.

2. José I. Gallegon, Historia de Durango I563-I9I0, M éxico, taller A. M ijares y hno., 1974, p. 164 .

3. Francisco de la M aza, La dudad de Durango. Notas de arte, M éxico, imprenta Gama, I948, p. 25 . 
El Señor de Mezquital.

Foto: M iguel V allebueno G arcinava.

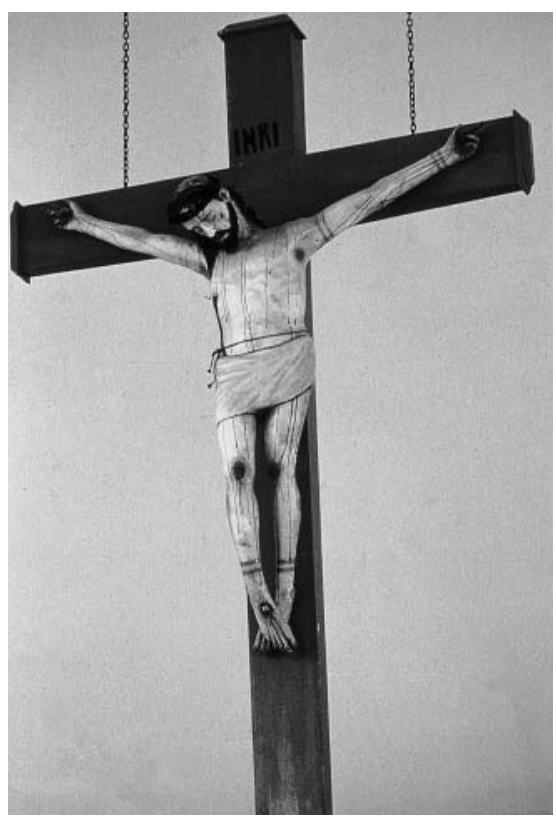

En el antiguo templo de los jesuitas, ahora llamado N uestra Señora de San Juan de los Lagos, anexo al edificio central de la Universidad Juárez del Estado de Durango, se encuentra un Crucifijo al que se le llama Señor del $M$ ezquital. D e acuerdo con los datos proporcionados por el presbítero Alberto del Campo, quien fue capellán del templo, después de terminado el conflicto cristero, en la década de los 1930, esta imagen fue llevada de la catedral a ese lugar. Esta figura es de madera, pero no presenta ningún rasgo del flechazo en la espinilla del que nos habla Arlegui. ¿Q ué pasó entonces? Al parecer, durante el tiempo en que el Cristo del Mezquital permaneció en la sacristía de la catedral estuvo también la otra imagen en el mismo lugar. Con el tiempo las dos fueron confundidas hasta que la de madera fue sacada y llevada al templo de la Virgen de San Juan de los Lagos y la de caña quedó en el olvido. H acia 1970 cuando se terminó de construir el templo del Santo N iño de Atocha, situado al norte de la ciudad en la colonia Benjamín M éndez, la figura de caña fue sacada de la catedral y colocada en la parte alta del nuevo templo, colgada sobre el presbiterio en una cruz moderna.

Gracias a una plática con monseñor Juan Antonio Díaz, quien estuvo encargado de la catedral durante muchos años, supe que en el nuevo templo 
de Santo N iño se encontraba un Cristo de caña que había estado antes en la catedral. Al verlo y compararlo con el que se encuentra en el templo de la Virgen de San Juan de los Lagos, resultó evidente que el C risto de caña de la iglesia del Santo N iño de Atocha es el que corresponde al Señor del M ezquital. Exhibe claramente en la espinilla una herida que la leyenda atribuye al flechazo tepehuán. Así queda identificado el Cristo de caña que tanta veneración tuvo en $\mathrm{D}$ urango, hasta que fue sacado del templo franciscano, y una de las esculturas más antiguas que se encuentran en el norte de M éxico. \$ 